\title{
Investigation of dynamic electricity line rating based on neural networks
}

\section{Levente Rácz,}

\section{Bálint Németh}

Budapest University of Technology

and Economics,

Egry József St. 18,

1111 Budapest, Hungary

Email: racz.levente@eszk.org
The security of supply with a high level of operational safety and security has a prominent role in the domestic and international electricity networks. Due to continuous growth of consumer demand, the integration of renewable energy sources and other related changes in the market issues, a number of problems and challenges with the operation and utilization of the existing network have been identified. The need for a higher level of transmission capacity for the transmission network is one of the major challenges in the electricity network.

Dynamic Line Rating (DLR) is a new generation of transfer capacity methods that can provide a cost-effective solution for the security of supply problems without re-planning the existing infrastructure background. The currently used Static Line Rating allows operators to calculate transfer capacity determined by the worst-case of the weather conditions on the wires of a particular transmission line. Whereas practical applicability shifts to security, the result of this calculation method is almost $95 \%$ of time less than the real permissible load of the overhead lines. This potential can be exploited with the DLR by always adjusting the maximum current that can be transmitted on wires. These maximum current values are calculated from the real-time environmental conditions, thus the DLR does not only provide better security of supply, but also a higher level of availability.

The main issue of the article is to investigate the DLR based on the application of non-analytic computational methods different from the current calculations of the international standards (CIGRE, IEEE). The aim of this research is to create a neural network capable of recognizing patterns based on the weather data of previous years and the actual current values of the wires. In this way, it is not only possible to fine-tune, but also accelerate the applied calculation of maximum load capacity.

Keywords: Dynamic Line Rating, transfer capacity, overhead lines, soft computing, neural networks 


\section{INTRODUCTION}

Nowadays more and more high voltage overhead lines (OHL) are heavily loaded due to the increased power flow caused by cross-border trading and far located renewable energy sources. Thus, the Transmission System Operators (TSO) in many countries require development of the existing network. However, the construction of new transmission lines could be complicated due to strict legal regulation, not to mention the extremely high investment costs. According to these phenomena there is a general need to use the existing transmission system infrastructure more intensively. For this better exploitation of the grid, Dynamic Line Rating (DLR) could be a promising and cost-effective option [1-3].

It is widely known that the transmission system's capacity is calculated based on Static Line Rating (SLR), which means that the maximum ampacity of the overhead lines is determined from the worst case scenario of weather parameters. The main advantage of replacing SLR by DLR is that DLR uses real-time current from the SCADA (Supervisory control and data acquisition system) and also real-time meteorological parameters to exploit the real permissible capacity of the wires. Moreover, it is possible to involve weather forecast's data into calculating algorithms to assign the maximum load of the OHLs. By calculating transfer capacity with DLR, the maximum ampacity of the transmission lines is $10-30 \%$ higher in more than $95 \%$ of the time which is highly significant [1-3].

\section{DYNAMIC LINE RATING}

It is important to mention that Dynamic Line Rating is a promising option for existing infrastructures but cannot substitute the grid development. According to researches and existing applications, the exploitation of the grid can be better by taking the advantages of DLR.

\section{Advantages of DLR}

Two main advantage of DLR is increased capacity and improved safety of the system. As an additional benefit, DLR helps to increase the stability of the transmission network. At present, the N-k-1 principle is in force, where $\mathrm{N}$ means elements of the grid and $\mathrm{k}$ means the elements under maintenance. According to this principle, the stability of the system has to be maintained in case of another malfunction in the grid. However, with the application of DLR, it is possible to determine alternative energy transport paths. It is also important to mention that while the design and the construction of new transmission lines are quite expensive, the use of DLR is a cost-effective method for the TSOs [4].

Application of DLR has many other advantages: real-time load calculation, transmission capacity forecasting, increased system reliability and reduced risk of extreme weather conditions. On the other hand, under certain conditions the application of DLR could give rise to surplus thermal loading over the stability limit or induce too high reactive power losses that cannot been compensated with available regular methods. All in all, DLR has several different advantages,

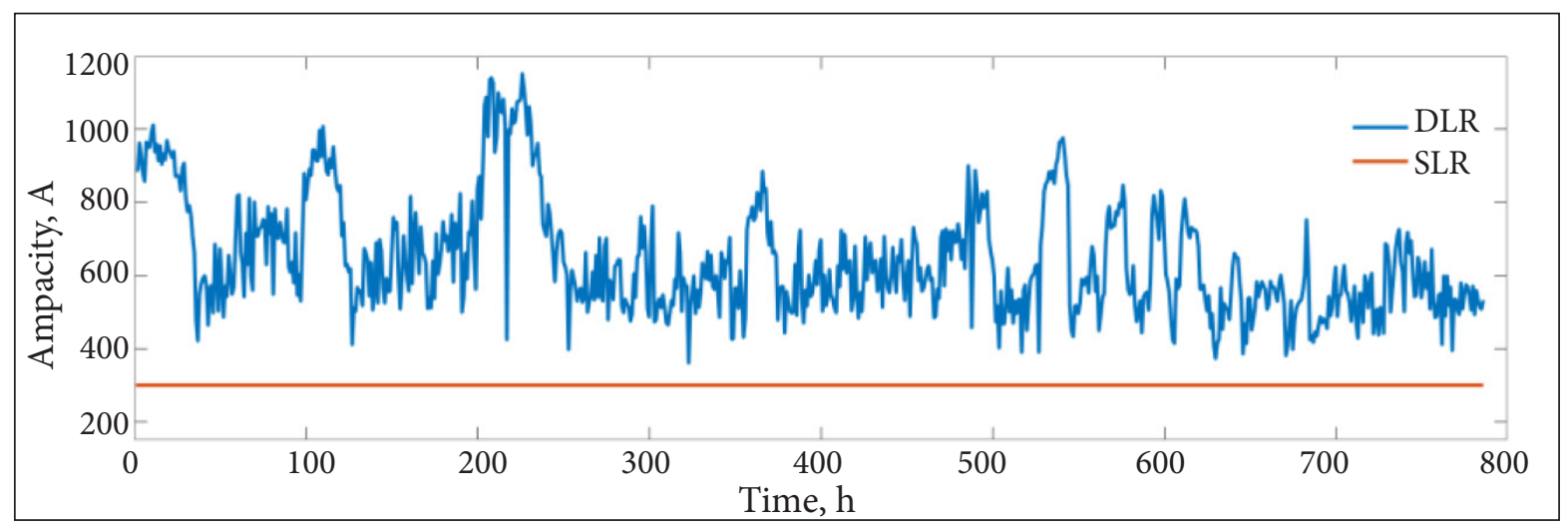

Fig. 1. Maximum ampacity in case of DLR and SLR 
but some basic issues have to be carefully considered before its application can be applied to each OHL $[3,4]$.

\section{Existing applications}

The aim of DLR is safety utilization of the existing transmission system's capacity based on real conditions in which the power line operates. There are several forms of DLR applied by the TSOs in the transmission system. One of these applications is the so-called seasonal DLR, when the maximum ampacity of the wires is calculated for both summer and winter period to exploit the extra capacity of the existing grid for the half of the year. In our article, DLR refers to the method of dynamic transmission line loadability, in which the chargeability of the wire is continuously calculated in real time. This method requires a lot of measured data and it is important to note that these required data need to be real-time ones. Calculation of the capacity of the wire is performed by a complex algorithm whose input parameters are the physical characteristics of the wire, the temperature of the wire, the ambient temperature, the wind speed, the wind direction, etc. The purpose of this paper is to present the currently accepted calculation algorithm of DLR and its replacement by a new black box model containing neural network, analyzing its errors and benefits [2].

\section{Standard models}

There are two worldwide known models in use to determine the ampacity via DLR: IEEE model and CIGRE model. These DLR models have been constantly evolving over the years thanks to new experiences and research. Literature containing the basics of the Dynamic Power Line (IEEE 738 and CIGRE 601 WG B2.43) has been revised several times and the next edition of the current edition is being edited.

It is important to mention that calculation of DLR is a demanding method, due to it two different problems have to be separated: determination of the weakest span and calculation of the DLR value. The weakest span represents the critical part of the transmission line so that it determines the thermal current limit for all spans has been performed.

Both IEEE and CIGRE models are based on a heat equation. On one side, the heat gain, while on the other side, the heat losses are listed [1]:

$$
P_{J}+P_{S}=P_{C}+P_{r}
$$

where

$P_{J}$ is Joule heating $[\mathrm{J}]$,

$P_{S}$ is solar heating [J],

$P_{C}$ is convective cooling [J], and

$P_{r}$ is radiative cooling [J].

The main disadvantage of such an empirical model is that it takes a long time to finalize it. The results provided by this algorithm make it possible to use the model, but there are many ways to improve the calculation methods to achieve even more accurate results. In the present case, the accuracy of these models was researched, but many results show their deficiencies.

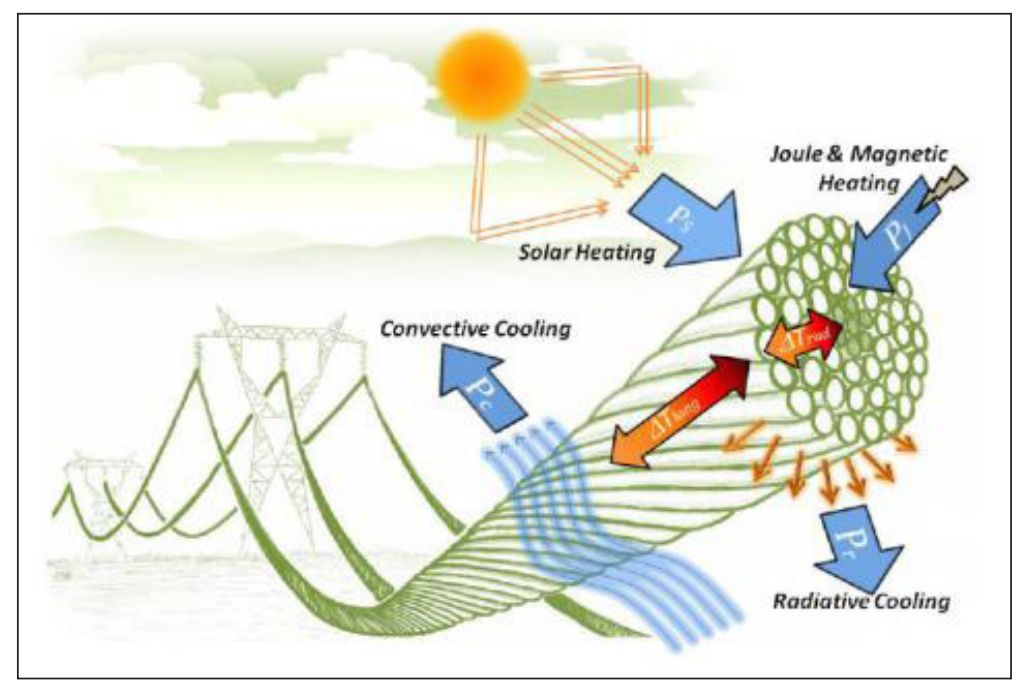

Fig. 2. Factors influencing DLR [1] 
One weakness of current models is that at different wind speed values the DLR results are quite different. Moreover, model (1) is a simplified model that contains many neglects (e.g. electromagnetic phenomena, crown effect losses, etc.), and these models are not able to take into account the cooling effect of the precipitation [5].

The aim of this research is to apply a neutral network capable of recognizing patterns based on weather data of previous years and actual current values of the wires. In this way, it is not only possible to fine-tune, but also accelerate the applied calculation of maximum load capacity and deal with the neglections of IEEE and CIGRE models. By using the so-trained neural network it could be possible to replace the currently used empirical models.

\section{APPLICABILITY OF SOFT COMPUTING METHODS}

For problems where the solving algorithm is unavailable or very complex, intelligent modelling and calculation procedures are required. In these situations, the experience, intelligence, individual perception and problem solving skills of engineers, namely soft computing, are put to the fore. In contrast to hard computing methods, the soft calculation methods are less stringent, the inputs and algorithms are much more subtle, thus better able to handle uncertainty, inaccuracy and approximations $[6,7]$.

Based on the above considerations, in some problem-solving cases the use of artificial intelligence-based methods can lead to results. Such artificial intelligence-based systems include expert systems, neural networks, fuzzy systems, genetic algorithms, probability arguments and other intelligent agents. These systems can be much easier to solve than conventional analytic, numerical algo- rithms by using conclusions, heuristic approaches, and adaptation of human problem solving [6,7].

In order to determine which soft computing varieties should be in use, it is necessary to look at how each of these options handles existing knowledge, data, the implication mechanism and whether they have the ability to implement learning and optimization tasks.

\section{Neural networks}

Due to properties of each method, only the neural networks and genetic algorithms can be applied for this new black box model since the goal is to create a trained system based on previous examples. Neural networks are computing systems based on human brain. This kind of networks are able to detect objects and patterns, and solving problems associated with them on a large number of data sets [8].

First of all, it can be concluded that neural networks work with relatively unstructured knowledge, mostly with data series and data sets. This existing knowledge is treated numerically. Due to this numerical knowledge, there is no possibility for logical operations or relationships to be realized, but there are also concluding mechanisms in this case. By the use of neural networks an analogous, associative-based conclusion is given to the desired result [9].

Considering learning and optimization, neural networks are in a favourable position compared to other soft computing types. Based on sample recognition and associative-based conclusions, the network can learn, recognize patterns in data and, in some cases, optimize them.

Overall, it can be concluded that the use of neural networks can be used to induce DLR analytic, numerical calculations. Using a new black box model with the neural network it is possible to determine the maximum allowable current on the transmission line from weather parameters [9].

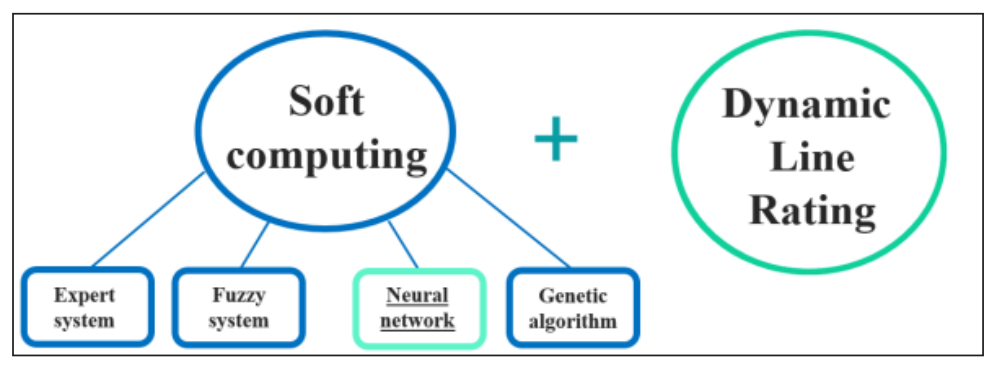

Fig. 3. Intelligent agents and DLR 


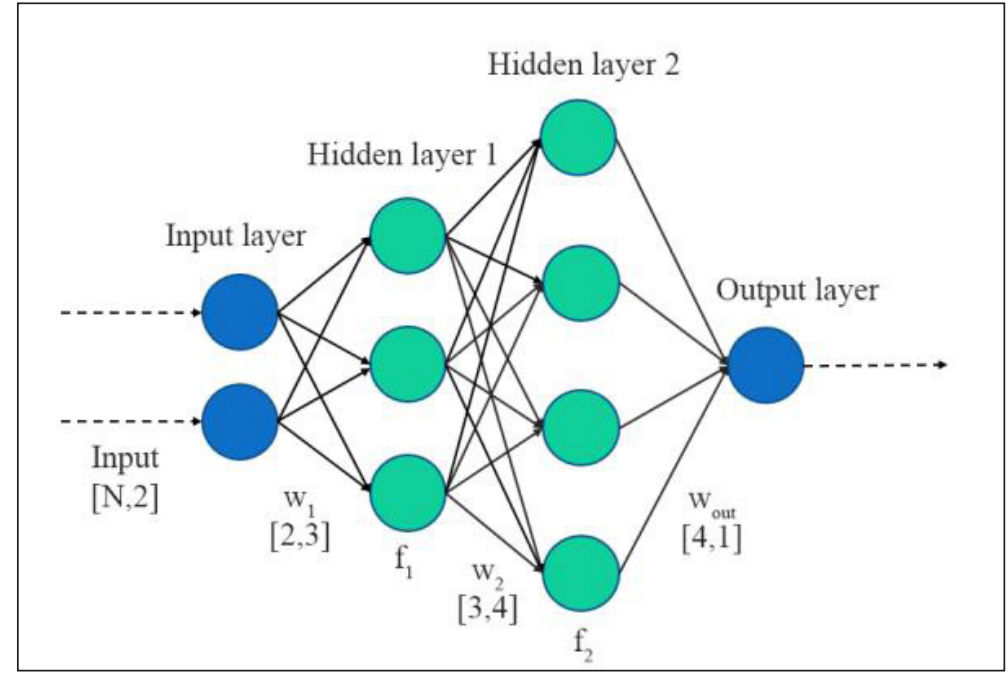

Fig. 4. The structure of a general neural network

\section{Data available for the new black box model}

DLR calculations require a huge amount of data. Available data can be split into two large groups. On the one hand, there is a need for weather forecasting, as it is possible to estimate the environmental parameters on which to determine the maximum flow and the maximum sag. On the other hand, real-time measurements are also needed to determine the parameters of the transmission line load in real time.

For weather forecasts, the forecasted data of existing weather stations are in use. Via the forecast, an estimated value, such as temperature, solar radiation, wind direction, speed, etc. gets available. However, it is important to mention that types and accuracy of weather forecasts are quite diversified. This neural network model does not include forecasted data, yet.

Sensors installed on the transmission line are used to correctly record the data measured in real time. The installed sensors measuring ambient parameters at specific intervals are able to determine, by analytic, numerical methods, the maximum value of the current that can be transferred through the wire. Most sensors measure the temperature of electric line, but there are devices that are able to monitor the angle of the lines horizontally, which makes it easier to determine the sag. In this case 3 weather parameters (solar radiation, wind, ambient temperature), the SCADA current and the temperature of the line formed the group of real-time data $[10,11]$. For the simulations mentioned below, an OTLM sensor was applied on the OHL. Temperature measurement was per- formed by direct measurement in the point on phase conductor. The deviation of the sensor is $\pm 2^{\circ} \mathrm{C}$.

\section{SIMULATIONS}

In order to expose the applicability of the investigated black box model, simulations were carried out with different types of neural networks in MATLAB. Via simulation, the structure of the network was also amended to find out the optimal result.

\section{Identification of a new black box DLR model}

The main goal of simulation is to substitute the existing DLR calculating methods with the use of a new black box model. There are two main steps in simulation, calculation of the line temperature with neural networks and after it determination of the maximum ampacity of the line in the weakest span.

The background of the black box model is the following: a sensor is installed on the line that monitors the temperature of the wire in real time. There is also real-time information about the solar radiation, the wind and the ambient temperature from weather stations. According to real-time line measurement, measured temperature of the line contains all environmental effects even those that are neglected in IEEE and CIGRE models. Knowing real-time and the maximum temperature of the line, the extra allowable Joule heating could be calculated from a simple heat equation. However, not all OHLs have 
a temperature measurement sensor on themselves, so calculation of the real-time line temperature can be executed via use of neural networks after a training method.

In order to carry out simulations, nominal and load data of a high-voltage transmission system running in a Central European country have been carried out. The two-phase, nominal voltage level of the transmission line system is $110 \mathrm{kV}$, its location is continental, that is, seasonal periodicity of environmental parameters can be distinguished and icing on the transmission line cannot occur during summer time. The tested wire type is $\mathrm{Al} / \mathrm{ACS} 240 / 40 \mathrm{~mm}^{2}$, one insulator is used per phase on the transmission line, while the maximum permissible temperature of the wire cannot rise over $40^{\circ} \mathrm{C}$ due to the limitation of the sag.

\section{Parameters of the neural network}

There are several types of neural networks depending on each parameter. Basically, two large groups can be distinguished: forward and backward neural networks. Neural networks are usually structured as follows: there is a certain number of inputs and a number of hidden layers, one output layer, and usually one output. Based on the analogy with the human body, the network contains any number of neurons, which in some cases are also called perceptron. These are the smallest structural units of the system that process information in conjunction with each other, and their internal states can be described in numerical form with the so-called activation value. During the teaching process, information activation functions extend from neuron to neuron, thereby modifying the weights and thresholds in the system, i.e. free parameters. This way, internal context of the system can be modified to reach more accurate output values [9].

The conductor temperature problem to be solved can be defined with an error minimization equation [6]:

$$
R_{e m p}(\bar{w})=\frac{1}{k} \cdot \sum_{i=1}^{k}\left(d_{i}-\operatorname{Net}\left(\bar{x}_{i}, \bar{w}\right)\right)^{2},
$$

where

$R_{\text {emp }}(\bar{w})$ is empirical risk functional,

$\bar{x}_{i}, \underline{w} \quad$ are free parameters of the system, and

$d_{i} \quad$ is the desired response to an $\bar{x}_{i}$ vector.

According to attributes of the neural networks, the defined problem can be solved with feedforward neural networks with $n$-dimension variables, where $n$ means the number of inputs. Using earlier results, a cascade type neural network belonging to the group of feedforward networks was applied in the model. The process of learning was chosen to be the Levenberg-Marquardt mechanism since this method, unlike other mechanisms, is able to locate the minimum error gradient even if it is far from the initial minimum value. In the system itself, 4 layers were added, 3 of them are hidden and 1 is the output layer. Four neurons in the first layer, 32-32 neurons in the second and third layers,

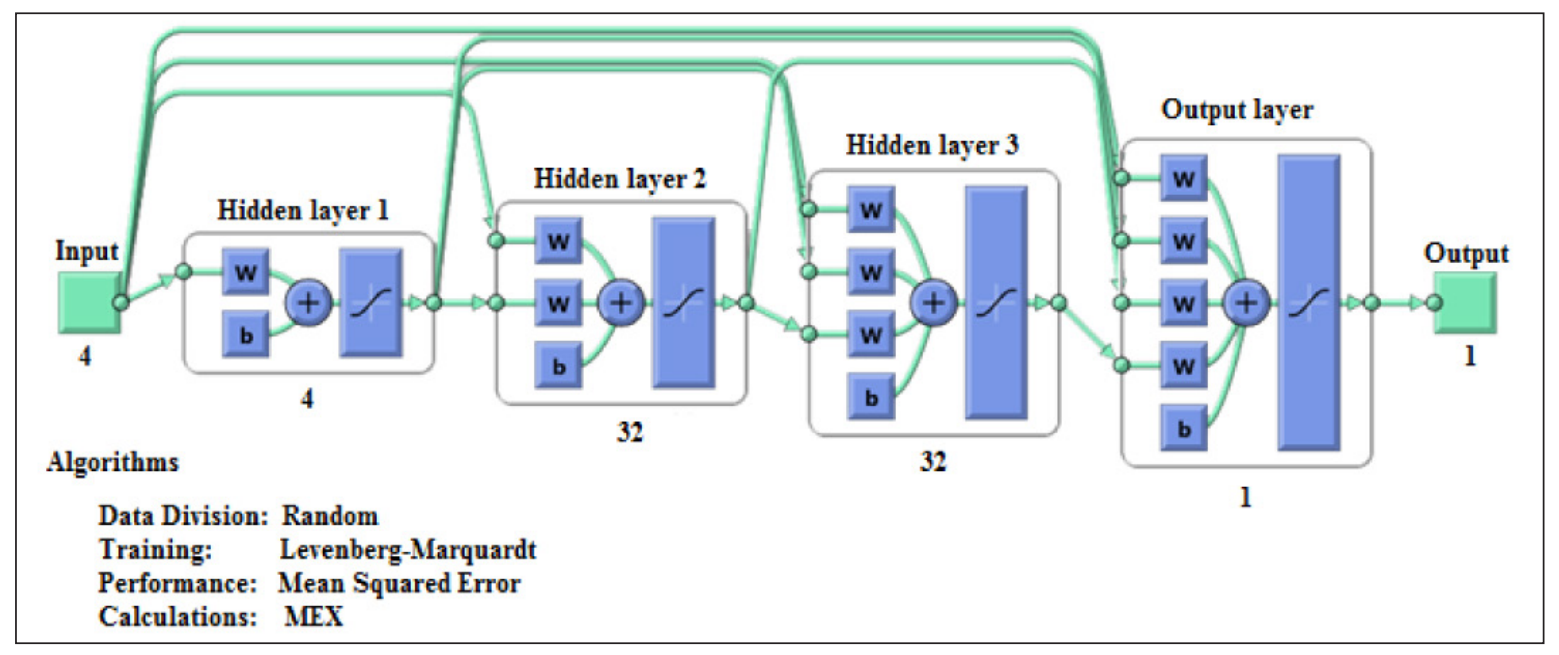

Fig. 5. The structure of the chosen neural network 
and only 1 neuron in the last output layer should be located.

In previous modelling, it was experienced that the limit is around at four layers, where the increased duration of teaching is more dominant than a slight change in the accuracy of the output result. For the simulation, more than 60 neurons were set up for increasing free parameters of the system.

During the simulation, one part of the input parameters was the environmental parameters and the other part was the current transferred through the wire. However, not all of the available environmental parameters were used for simulation. During the model, the air humidity, pressure and wind direction were not taken into account. For the first two parameters, previous simulation experiences have shown that their use do not significantly increase accuracy in the model, while due to a large number of emerging issues in the wind direction, it was better to ignore this parameter from the initial model. Thus, a total of 3 environmental parameters - wind speed, air temperature, and solar radiation - served as the input of the network. For later runs, it would be worth considering the wind direction and the amount of precipitation as possible input due to their prominent cooler effect.

In addition to the 4 input parameters, in all cases the output parameter was the wire temperature measured by an installed sensor. From the point of view of DLR, this is a favourable case because both the temperature of the wire and the actual current value indicated by the SCADA are directly measured values, meaning it is possible to see how the environmental parameters collectively modify the temperature generated by the real-time current of the wire.

\section{Learning method, validation and testing}

During simulation, environmental parameters in every 30 minutes of each day of March to October were used, so thousands of learning points were available for the system to realize the appropriate learning process. The reason for this was to eliminate weather conditions typical of each season. For the learning method, about $80 \%$ of the information was set to teach, while 10 and $10 \%$ for validation and testing. The teaching mechanism was carried out by modifying free parameters, i.e. changing the weights and thresholds in the system. The end of the teaching method was achieved by reaching a pre-set gradient minimum.

In Fig. 6 the black dots represent teaching, validation and testing data. The coloured lines (the blue, green and red ones) on the graphs display the desired result for the network. These lines serve as the most appropriate linear regression lines between the outputs and the targets. The $R$ value indicates the strength of the relation between the targets and outputs. If $R=1$, it indicates that outputs and targets are nearly linear. According to Fig. 6 training of the networks was successful.
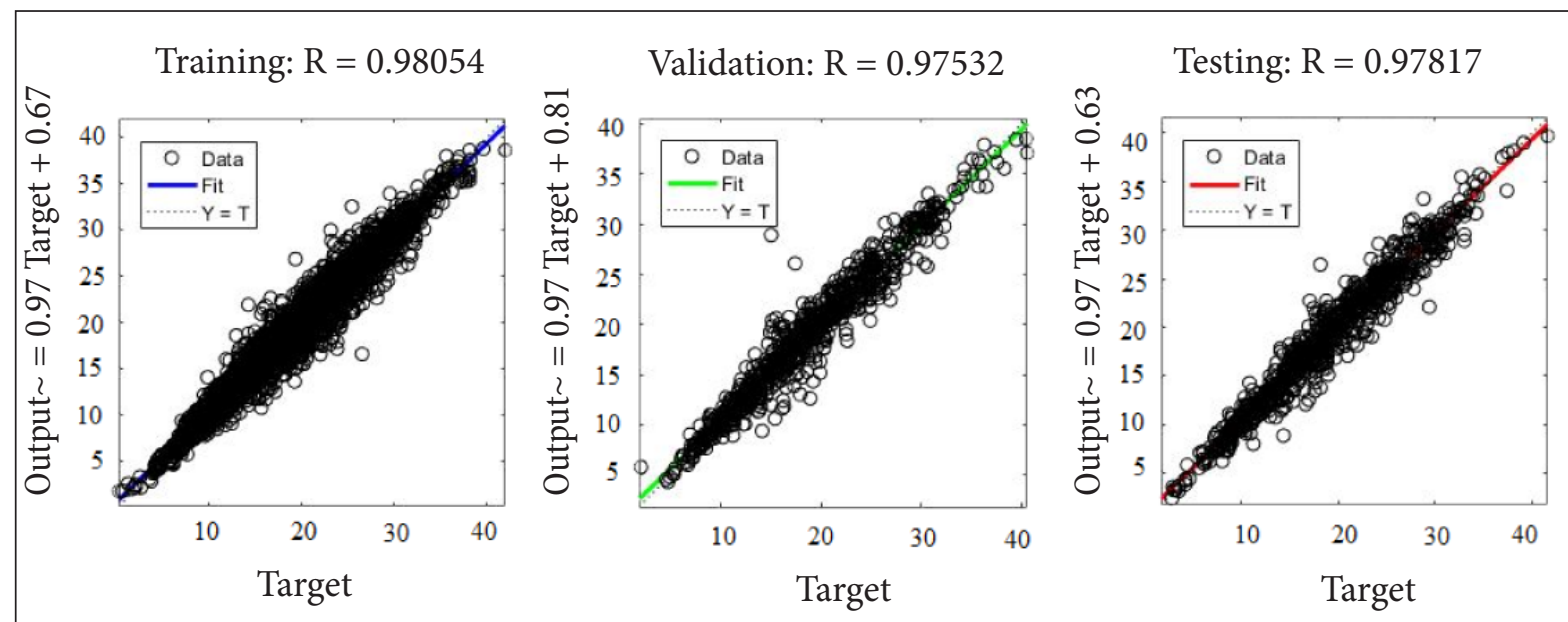

Fig. 6. The training, validation and test of the neural network 


\section{RESULTS}

Based on the simulations carried out, the neural network is able to calculate the temperature of the wire with an error of under $7 \%$, based on the actual current and environmental parameters. This $7 \%$ of the error can be accepted because this rate means about $1-2^{\circ} \mathrm{C}$ difference in the temperature, which roughly coincides with the accuracy of sensors.

In Fig. 7 the test of the network is presented. During teaching, intentionally, the last days of 6 months did not appear among the elements. The data of these last days were applied during this testing, meaning this test was under real circumstances. In Fig. 7, therefore, the line temperatures of the last days of the 6 months were compared to the results provided by the neural network. As it is shown, the curve deriving from the neural network follows the expected sensor values.
One of the main goals of the electricity system is to use the maximum capacity of the network besides security. Accordingly, there is a realistic need for the model to be able to determine the value of the current that can be carried out through the wire by the environmental parameters. As a second step, knowing the current temperature of the line, the maximum ampacity of the system can also be calculated from a heat equation.

In Fig. 8 the maximum ampacity of the line calculated from CIGRE model, compared to the ampacity value calculated from the neural network black box model is presented. As 2 curves are similar, it can be stated that the initial black box model is applicable for DLR calculation on the transmission lines. However, it is necessary to develop the black box model in order to obtain better results.

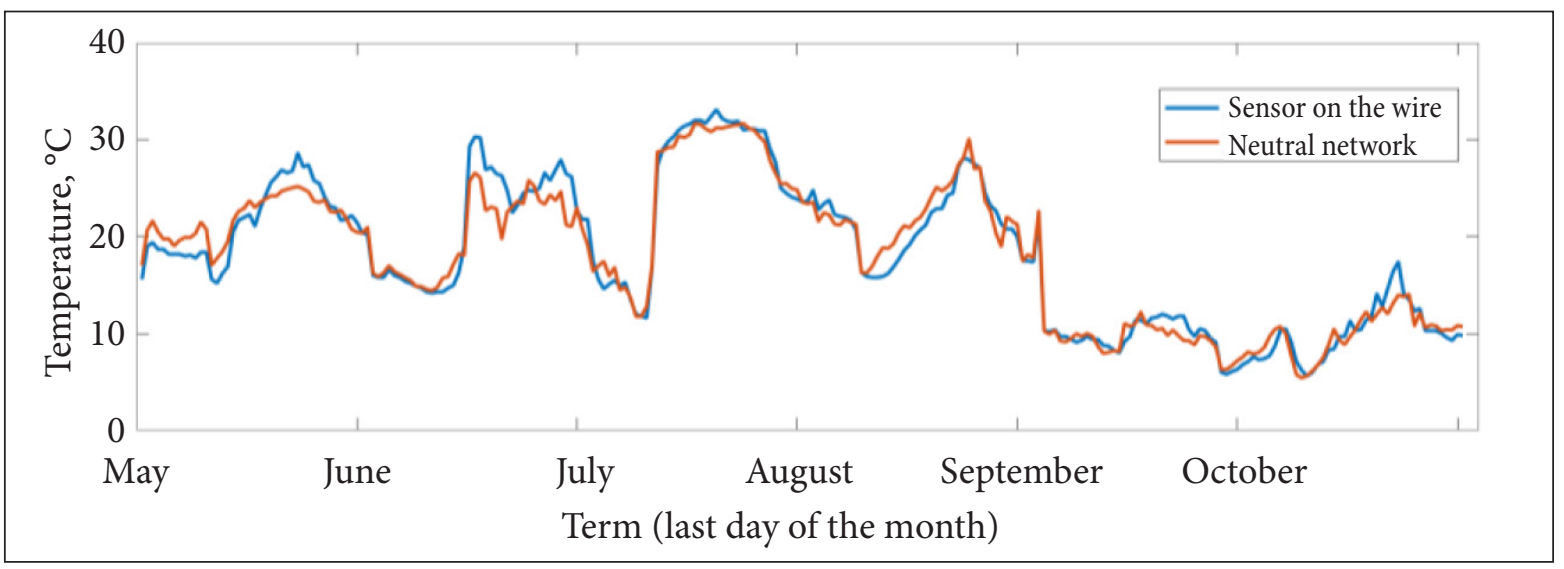

Fig. 7. The temperature of the wire as a function of time

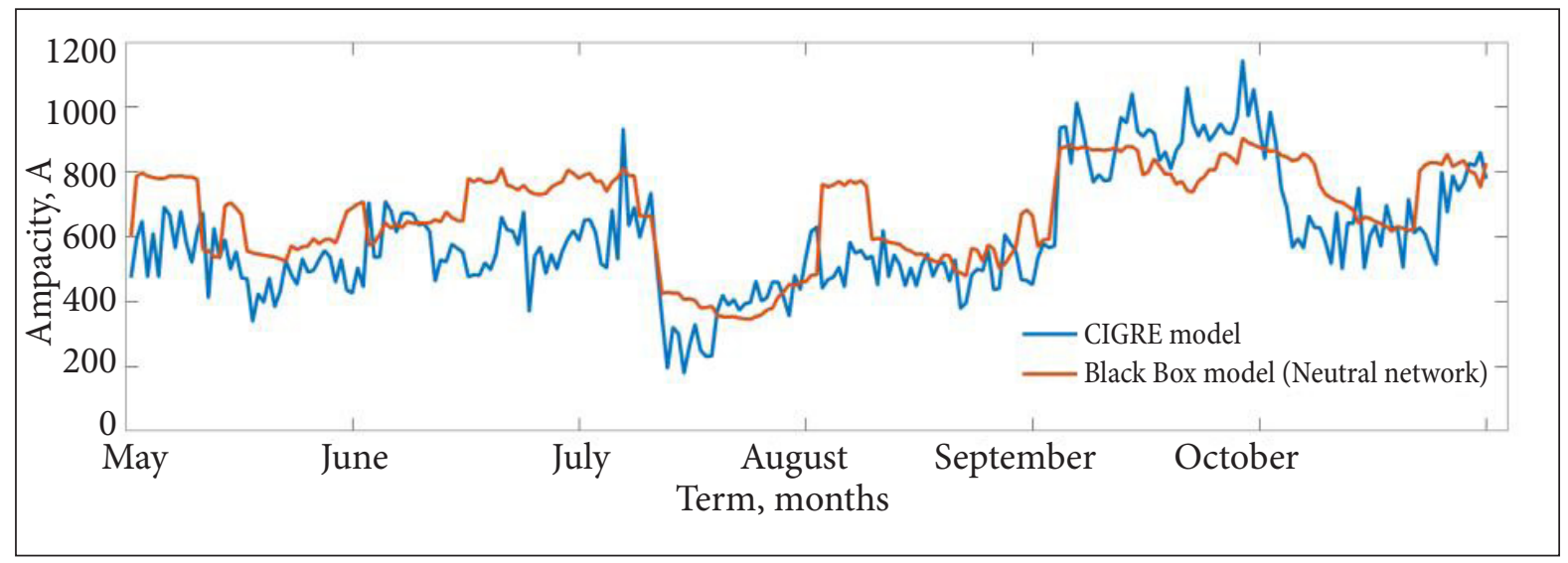

Fig. 8. DLR value of the last days of the 6 months as a function of time 


\section{CONCLUSIONS}

It can be stated that in the designation of DLR, an analytical numerical method that calculates the maximum allowable current value from the environmental parameters in the transmission system can be replaced by using soft computing methods. Based on the structure and numeric values of available data, the use of neural networks seems to be useful for obtaining results. This is reinforced by the fact that the system thus designed should be able to analyse the relationships between previous data series, the input and output values, and to deduct the correct conclusions from these. This means, in essence, that the system must be able to learn, which is possible in soft computing methods mainly through the use of neural networks. In this article, a new black box model and parameters of the chosen neural network have been detailed. Then, with real-time weather parameters, test runs were carried out on wires of the Central European transmission line system. In calculation of the line temperature the average error of the network was below 7\%, which can be accepted according to the accuracy of temperature sensors. It is also possible to calculate the DLR values from a heat equation with the use of the initial black box model. However, the network could be clarified and fine-tuned by using more learning data and giving more weight to the cooling effect of the wind. The calculation of ampacity can also be more precise with the accurate measurement of the wire's time constant and completion of the model with wind direction as input factor. All in all, the performed simulations seem to be a good basis for further researches.

\section{ACKNOWLEDGEMENTS}

This work has been developed in the High Voltage Laboratory of Budapest University of Technology and Economics within the boundaries of FLEXITRANSTORE and BEST PATHS international projects. FLEXITRANSTORE stands for "An Integrated Platform for Increased FLEXIbility in smart TRANSmission grids with STORage Entities and large penetration of Renewable Energy Sources". BEST PATHS stands for "BEyond State-of-the-art Technologies for repow- ering AC corridors and multi-Terminal HVDC Systems".

Supported BY the UNNKP-17-2-I New National Excellence Program of the Ministry of Human Capacities

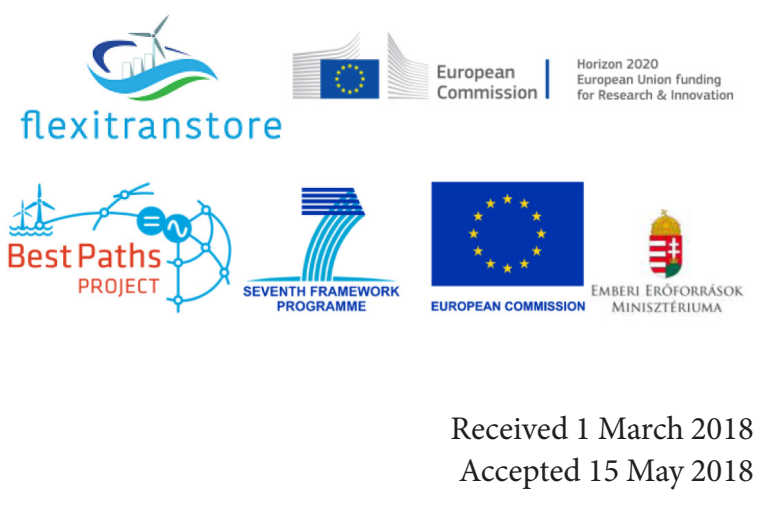

References

1. CIGRE 601 WG B2.43 - Guide for thermal rating calculations of overhead lines, 2014.

2. Twenties Project, Final report, 2013. Link to the internet <https://hub.globalccsinstitute.com/sites/ default/files/publications/138053/Twentiesproject.pdfhub.globalccsinstitute.com/sites/default/ files/publications/138053/Twenties-project.pdf >

3. Dynamic Line Rating for Overhead Lines - V6, CE TSOs current practice. ENTSOE, 2015. Link to the internet <www.entsoe.eu/Doc uments/ SOC\%20documents/Regional_Groups_Continental_Europe/Dynamic_Line_Rating_V6.pdf >

4. McCall J. C., Goodwin T. Dynamic Line Rating as a Means to Enhance Transmission Grid Resilience. CIGRE US National Committee, 2015.

5. Holbert K. E., Heydt G. T. Prospects for dynamic transmission circuit ratings. ISCAS 2001. The 2001 IEEE International Symposium on Circuits and Systems, 6-9 May 2001, Sidney, NSW, Australia.

6. Haykin S. Neural Networks: A Comprehensive Foundation. Hamilton: Pearson Education, 1999. 823 p. ISBN 81-7808-300-0.

7. Aradi P., Graff J., Lipovszki G. Computer Simulation. Budapest, 2014 [in Hungarian]. Link to the internet <http://www.mogi.bme.hu/TAMOP/ szamitogepes_szimulacio/math-index.html>

8. Altrichter M., Horváth G. Neural Networks. Budapest: Hungarian Edition Panem Könyvkiadó Kft, 2006. 432 p. ISBN-10 9-635454-64-3 [in Hungarian]. 
9. Borgulya I. Neural Networks and Fuzzy Systems. Budapest-Pécs: Dialóg Campus Kiadó, 1998. ISBN 9639123277 [in Hungarian].

10. Gubeljak N., Banić B., Lovrenčić V., Kovač M., Nikolovski S. Preventing transmission line damage caused by ice with smart on-line conductor monitoring. International Conference on Smart Systems and Technologies (SST) 2016.

11. Lovrenčić V., Gabrovšek M., Kovač M., Gubeljak N., Šojat Z. The contribution of conductor temperature and sag monitoring to increased ampacities of overhead lines (OHLs). DEMSEE'15 10th International Conference on Deregulated Electricity Market Issues in South Eastern Europe, 24-25 September 2015, Budapest, Hungary.

Levente Rácz, Bálint Németh

\section{DINAMINIS ELEKTROS LINIJOS PRALAIDUMO VERTINIMAS NEURONINIŲ TINKLŲ PAGRINDU}

\section{Santrauka}

Tiekimo saugumas, užtikrinantis aukštą režimų patikimumo ir saugumo lygi, yra svarbi dedamoji vidaus ir tarpsisteminiuose elektros tinkluose. Atsižvelgiant i nuolatini vartotojų paklausos didejimą, atsinaujinančių energijos išteklių integravimą ir kitus su tuo susijusius rinkos pokyčius, nustatytos kelios problemos ir iššūkiai, sietini su esamo tinklo veikimu ir naudojimu. Didesnių perdavimo tinklo pralaidumų poreikis yra vienas didžiausių elektros tinklo iššūkių.
Dinaminis linijos ịvertinimas yra naujos kartos perdavimo pajėgumų nustatymo metodas, kuris gali būti ekonomiškai efektyvus tiekimo saugumo problemų sprendimas, nekeičiant esamos tinklų infrastruktūros. Šiuo metu naudojamas statinis linijos pralaidumo įvertinimas leidžia operatoriams apskaičiuoti perdavimo pajègumus, nustatytus konkrečios perdavimo linijos laidų oro sąlygų blogiausiu atveju. Kadangi praktinis pritaikymas remiasi saugumu, šio skaičiavimo metodo rezultatas beveik 95 \% laiko yra mažesnis už faktinę leistiną oro linijų apkrovą. Šis potencialas gali būti panaudotas atliekant dinaminị linijos ịvertinimą, visada koreguojant maksimalią srovę, kurią galima perduoti laidais. Šios didžiausios srovès vertès apskaičiuojamos pagal realaus laiko aplinkos sąlygas, todèl dinaminis linijos ịvertinimas ne tik užtikrina geresnị tiekimo saugumą, bet ir aukštesnị leistinumo lygi.

Pagrindinis straipsnio tikslas yra pateikti dinamini linijos ịvertinimą, pagrịstą neanalitiniais skaičiavimo metodais, kitokiais nei dabartiniai skaičiavimai pagal tarptautinius standartus (CIGRE, IEEE). Šio tyrimo tikslas - sukurti neuroninị tinklą, galintị atpažinti apkrovų grafikus, remiantis ankstesnių metų orų duomenimis ir faktinėmis elektros srovès laiduose vertėmis. Tokiu būdu galima ne tik tiksliai suderinti, bet ir pagreitinti taikomą didžiausios apkrovos skaičiavimą.

Raktažodžiai: dinaminis elektros linijos įvertinimas, pralaidumas, oro elektros perdavimo linijos, kompiuterinis modeliavimas, neuroniniai tinklai 